\title{
Somatostatin Receptor Scintigraphy in Patients with Carcinoid Tumors
}

\author{
Dik J. Kwekkeboom, M.D., ${ }^{1}$ Eric P. Krenning, M.D. ${ }^{1,2}$ \\ ${ }^{1}$ Department of Nuclear Medicine, University Hospital Dijkzigt, 40 Dr. Molewaterplein, 3015 GD Rotterdam, The Netherlands \\ ${ }^{2}$ Department of Internal Medicine III, University Hospital Dijkzigt, 40 Dr. Molewaterplein, 3015 GD Rotterdam, The Netherlands
}

\begin{abstract}
In $80 \%$ to $90 \%$ of patients with carcinoids, tumor sites can be detected with [ ${ }^{111}$ In-DTPA-D-Phe $\left.{ }^{1}\right]$-octreotide scintigraphy. Unexpected, additional localizations are reported in one-third to two-thirds of patients. In a group of 52 patients, we analyzed the results of various combinations of octreotide scintigraphy and conventional imaging. Octreotide scintigraphy, alone or in combination with other imaging modalities, led to the detection of more tumor sites than any combination of conventional imaging techniques. The combination of octreotide scintigraphy, chest radiography, and ultrasonography of the upper abdomen led to the detection of lesions in all patients in whom they could be demonstrated by any imaging means, with a sensitivity of $87 \%$ in terms of the number of detected lesions. The calculated cost for this imaging regimen was higher than for the combination of conventional imaging as applied in our group. However, the benefit was the detection of at least one lesion in $11 \%$ of patients in whom with conventional imaging no abnormalities were found. Moreover, if the results from our patient group were extrapolated to a group of 100 patients, the advantage in terms of the number of extra lesions detected would be 65 extra lesions per 100 patients. The detection of more tumor sites in patients who are known to have one tumor localization with conventional imaging may be essential when deciding whether to perform surgery. Octreotide scintigraphy can be used to localize tumors, direct the choice of medical therapy, and (expected in the near future) select patients for radiotherapy. The impact on patient management is fourfold: Octreotide scintigraphy may detect resectable tumors that would be unrecognized with conventional imaging techniques; it may prevent surgery in patients whose tumors have metastasized to a greater extent than can be detected with conventional imaging; it may direct the choice of therapy in patients with inoperable tumors; and in the future it may be used to select patients for radionuclide therapy.
\end{abstract}

Detection of carcinoids is often due to the clinical signs and symptoms of hormone overproduction. The tumor may also be diagnosed because of local expanding growth or a chance radiologic or surgical finding.

When the tumor has not metastasized, or when only limited, localized spreading to the liver has occurred, the treatment of choice is surgery. In most patients with inoperable disease and carcinoid syndrome, treatment with the somatostatin analog octreotide causes a decrease of urinary 5-hydroxyindoleacetic acid (5-HIAA) levels and alleviation of symptoms [1-4]. For those patients who have somatostatin receptor-negative tumors, chemotherapy is indicated [5].

In patients with carcinoids, the localization of tumor sites with

Correspondence to: D.J. Kwekkeboom, M.D. conventional imaging means may be difficult [3]. Yet optimal information on these sites may be important when localizing a solitary resectable tumor and staging the extent of the tumor when the choice of treatment depends on this information.

Large numbers of high affinity somatostatin-binding sites have been found on carcinoid tumors [6, 7]. Over the past few years, in vivo visualization of carcinoids using a radiolabeled somatostatin analog, $\left[{ }^{111}\right.$ In-DTPA-D-Phe $\left.{ }^{1}\right]$-octreotide, has been reported by various groups. The results obtained by us and others are summarized here, and the implications of the findings regarding patient management are discussed.

\section{Protocol of Somatostatin Receptor Imaging}

The recommended dose of $\left[{ }^{111}\right.$ In-DTPA-D-Phe $\left.{ }^{1}\right]$-octreotide to be administered intravenously is approximately $200 \mathrm{MBq}$. With such a dose it is possible to perform single-photon emission computed tomography (SPECT), which may increase the sensitivity for detecting octreotide receptor-expressing tissues. It also provides better anatomic delineation than do planar views. Because of bowel contamination, the use of laxatives is highly recommended starting from the moment of injection.

Planar and SPECT images are obtained with a large field of view gamma camera equipped with a medium-energy parallelhole collimator. The pulse height analyzer windows are centered over both ${ }^{111}$ In photon peaks (172 and $245 \mathrm{keV}$ ) with a window width of $20 \%$. Data from both windows are added to the acquisition frames. The acquisition parameters for anterior and posterior planar images are (1) $128 \times 128$ word matrix; (2) images of head/neck: 300,000 preset counts (or maximum 15 minutes) at 24 hours and 15 minutes preset time $(\approx 200,000$ counts $)$ at 48 hours after injection; (3) the remainder of the body with separate images of the chest (including as little as possible of the liver and spleen), upper abdomen (including liver/spleen and kidneys) and lower abdomen: 500,000 counts (or maximum 15 minutes). For SPECT images these parameters are (1) single head camera: (a) 60 projections, (b) $64 \times 64$ word matrix, (c) at least 45 to 60 seconds acquisition time per projection; or (2) three-head camera: (a) 120 projections, (b) $64 \times 64$ word matrix, (c) at least 30 seconds acquisition time per step ( 45 seconds for SPECT of the head). If the time required to obtain these counts for the planar views is short, especially when tissues with relatively high accumulation 

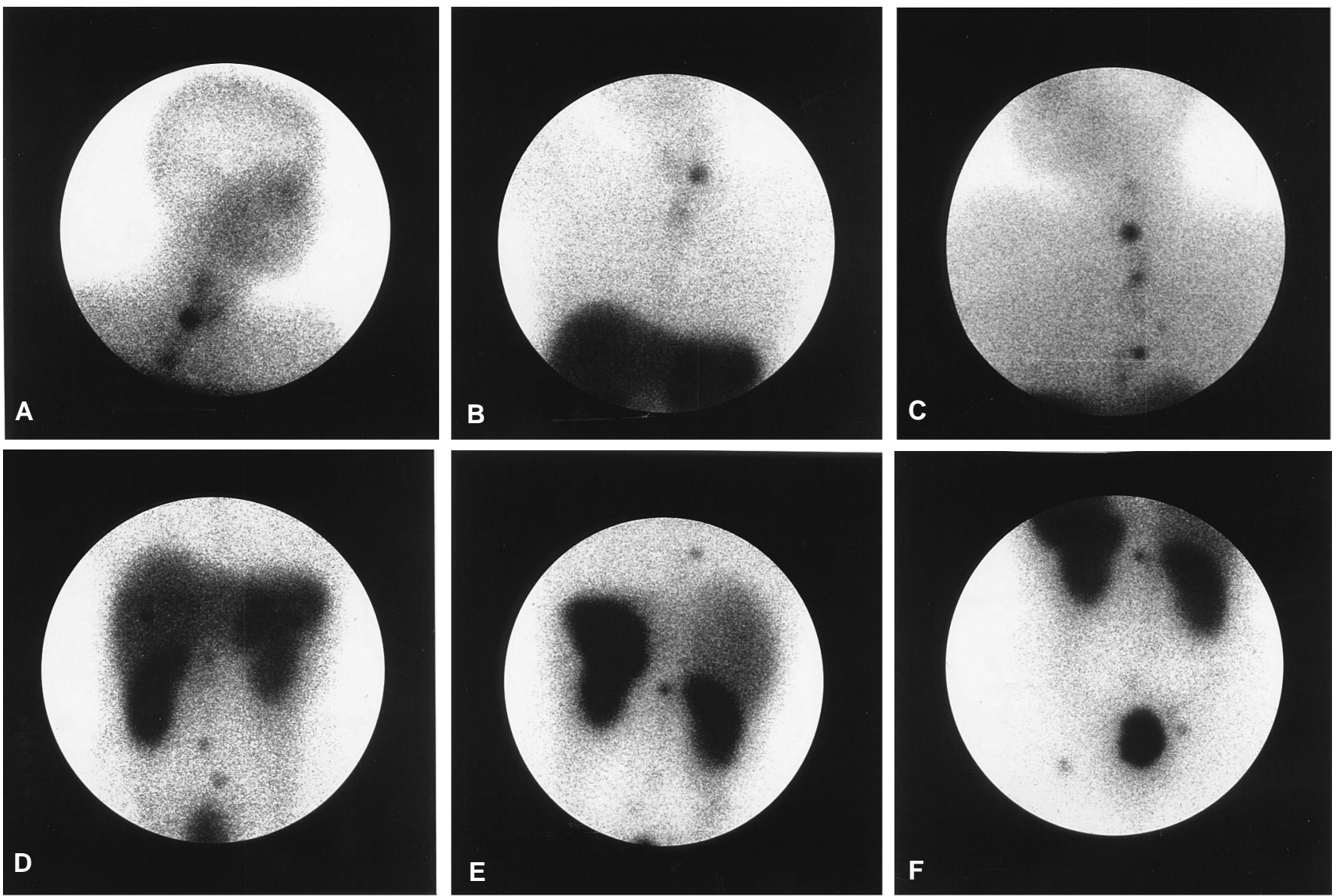

Fig. 1. Somatostatin receptor imaging in a patient with carcinoid tumours, 24 hours after injection of $\left[{ }^{111}\right.$ In-DTPA-D-Phe ${ }^{1}$-octreotide. Right lateral image of the head and neck (A), anterior (B) and posterior (C) images of the thorax, and anterior (D) and posterior (E) views of the abdomen. F. Posterior view of the lower abdomen and extremities. Note the clear uptake of radioactivity in multiple sites, among which are skeletal and lymph node localizations.

(e.g., abdominal organs) are included in the field of view, additional images with a longer counting time (up to 15 minutes per planar view) are necessary to visualize lesions with low somatostatin receptor density. The above-mentioned counting times per projection for planar imaging with a single head camera imply the need for an appropriate (long) duration of whole-body scintigraphy with a dual head camera (e.g., at least 40 minutes from head to pelvis). The need for SPECT studies is inevitable, especially if tumors are located in the abdomen and not visualized on planar images because of overprojection by other tissues or organs. SPECT analysis is performed with a Wiener filter on original data. The filtered data are reconstructed with a Ramp filter.

Planar and SPECT studies are preferably performed 24 hours after injection of the radiopharmaceutical. Planar studies after 24 and 48 hours can be carried out with the same protocol. Repeat scintigraphy after 48 hours is especially indicated when 24-hours scintigraphy shows accumulation in the abdomen, which may also represent radioactive bowel content [8].

\section{Results and Discussion}

We studied a group of 52 patients diagnosed as, suspected of, or at risk of having carcinoid tumors in whom scintigraphy with

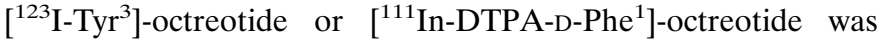
performed [9]. Accumulation of labeled octreotide at supposed tumor sites was found during octreotide scintigraphy in 32 of 37 patients $(86 \%)$ with histologically proved carcinoids, 3 of 11 patients who were thought to be surgically cured of carcinoids, and 4 of 4 patients who were clinically suspected to have a carcinoid [9]. In 27 patients (52\%) accumulation of radioactivity was found at previously unsuspected sites not recognized with other imaging techniques. Histologic or radiologic evidence that these additional sites indeed represented tumors was obtained in 10 patients for whom relevant follow-up was available. Visualization of the carcinoids did not depend on the site of the tumor or on the presence or absence of hormonal hypersecretion, as measured by urinary 5-HIAA and serum $\alpha$-subunit concentrations. An example of somatostatin receptor imaging in a patient with carcinoid tumors is given in Figure 1.

With octreotide scintigraphy, accumulation of radioactivity at known tumor sites was found in $86 \%$ of our patients with histologically proved carcinoid tumors. Comparable percentages were found by other groups. Joseph et al. [10] reported positive findings with octreotide scintigraphy in 26 of 32 patients with carcinoids (81\%), and additional tumor localizations were de- 
Table 1. Comparison between lesions found with conventional imaging techniques and octreotide scintigraphy in 52 patients.

\begin{tabular}{llllc}
\hline Localization & Only Conv & Conv + Oc & Only Oc & Total \\
\hline Extrahepatic & 16 & 40 & 53 & 109 \\
Liver & 12 & 12 & 1 & 25 \\
\hline
\end{tabular}

Conv: lesions found only with conventional imaging; Oc: lesions found only with octreotide scintigraphy; Conv + Oc: lesions found with both investigations.

tected in one-third of patients. Westlin et al. [11] detected tumor sites with octreotide scintigraphy in 31 of 40 patients with carcinoids $(78 \%)$ and demonstrated unexpected tumor localizations in $32 \%$ of patients. Ahlman et al. [12] reported a sensitivity of $84 \%$ for octreotide scintigraphy in 27 patients with carcinoids, whereas unexpected tumor localizations, not recognized despite computed tomography (CT) scanning and ultrasonography being performed in all patients, were demonstrated in 19 patients $(70 \%)$. Verification, histologically or radiologically, of these extra findings was obtained for 19 of 21 localizations in patients for whom follow-up was available. Octreotide scintigraphy was the sole imaging modality demonstrating tumor sites in four patients. Interestingly, octreotide scintigraphy changed the clinical management in eight patients: Five patients had repeat surgery leading to complete remission, and tumor reduction was achieved in three patients [12].

In the group of 52 patients we studied [9], 134 lesions were demonstrated with a combination of conventional imaging techniques and octreotide scintigraphy. The detection of these lesions with conventional imaging, octreotide scintigraphy, or a combination of these methods is presented in Table 1 . The sensitivity of the combined conventional imaging techniques that were applied and octreotide scintigraphy were 80 of 134 lesions (60\%) in 39 of 44 patients $(89 \%)$ and 106 of 134 lesions $(79 \%)$ in 39 of 44 patients $(89 \%)$, respectively. These figures did not differ significantly from those obtained in the group of 37 patients with histologically proved tumors.

Comparing the results of octreotide scintigraphy and conventional imaging techniques, we assumed the total number of lesions to be the total lesions visualized by any technique. This assumption was based on several grounds: (1) It applies to any imaging technique that it can only demonstrate disease-related localizations within a certain probability. The ultimate proof, histology, cannot always be obtained for every visualized lesion, especially if a tumor has metastasized. (2) Limitations in the capability to demonstrate tumors exist for all imaging techniques. In this respect, "occult" tumors, such as hormonally active tumors whose presence is certain on biochemical grounds but cannot be visualized by any technique, are a good example. (3) In a number of patients in whom octreotide scintigraphy demonstrated otherwise unrecognized tumor localizations and in whom follow-up was available, histologic proof was obtained afterward (see above).

In a cost-benefit analysis [13] we evaluated 15 combinations of imaging techniques for their cost and sensitivity. The costs of various diagnostic procedures were calculated taking into account personnel costs, cost of materials, equipment costs, and housing and overhead costs. Various combinations of imaging techniques were analyzed for their cost and sensitivity in terms of the number of lesions detected and the number of patients in whom at least one lesion was demonstrated. It was found that octreotide scintigraphy, alone or in combination with other imaging modalities, led to the detection of more tumor sites than any combination of conventional imaging techniques. The combination of conventional imaging techniques applied in our group led to the detection of only $60 \%$ of tumor sites and failed to detect any site in $11 \%$ of patients. The combination of octreotide scintigraphy, chest radiography, and ultrasonography of the upper abdomen led to the detection of lesions in all patients in whom by any imaging means they could be demonstrated, with a sensitivity of $87 \%$ in terms of the number of detected lesions. The calculated cost for this imaging regimen was higher than for the combination of conventional imaging as applied in our group. However, the benefit was the detection of at least one lesion in $11 \%$ of patients in whom, with conventional imaging only, no abnormalities were found. Moreover, if the results from our patient group were extrapolated to a group of 100 patients, the advantage in terms of the number of extra lesions detected was 65 extra lesions per 100 patients. The detection of more tumor sites in patients who were known to have only one tumor site by conventional imaging may be essential when deciding whether to perform surgery. Because of the impact on patient management, we concluded that especially because of the number of patients in whom otherwise no tumor was demonstrated the proposed imaging strategy of octreotide scintigraphy, chest radiography, and ultrasonography of the upper abdomen justifies the greater cost compared to various combinations of conventional imaging techniques [13].

It is important to determine whether a carcinoid has metastasized when the intended treatment is surgery. When the tumor has metastasized, it may be important to assess also the extent of tumor spread in order to evaluate the benefit of medical treatment and to anticipate or prevent future complications. When the tumor has not metastasized or there is only limited, localized spread to the liver, the treatment of choice is surgery. In this respect, detection of an otherwise unrecognized solitary tumor is crucial to patient management. In our group, as in the patient group described by Ahlman et al. [12], solitary tumors or tumors with limited spread were missed with conventional imaging and detected with octreotide scintigraphy in several patients.

Of special interest in this respect is a study by Moertel et al. [14], who performed a long-term study of 150 patients with carcinoid tumors of the appendix. No metastases were found from tumors $<2.0 \mathrm{~cm}$ in largest dimension, whereas metastases were observed from 3 of 14 lesions $\geq 2 \mathrm{~cm}$ and 4 of 9 lesions $\geq 3 \mathrm{~cm}$. The authors concluded that right hemicolectomy seems justified in young patients with tumors $\geq 2 \mathrm{~cm}$ who have a low risk of operative morbidity or mortality. Octreotide scintigraphy in these patients might provide useful additional information.

In patients with inoperable disease and carcinoid syndrome, treatment with octreotide is the treatment of choice. For those patients who have somatostatin receptor-negative tumors, chemotherapy is indicated [5]. In patients with carcinoid syndrome, octreotide scintigraphy, because of its ability to demonstrate somatostatin receptor-positive tumors, can be used to differentiate between patients who are likely to respond favorably to octreotide treatment and those who are better treated with chemotherapy.

Lastly, the therapeutic potential of radiolabeled somatostatin analogs should be mentioned. Somatostatin analogs with chelating groups capable of binding $\beta$-emitting radionuclides are not yet 


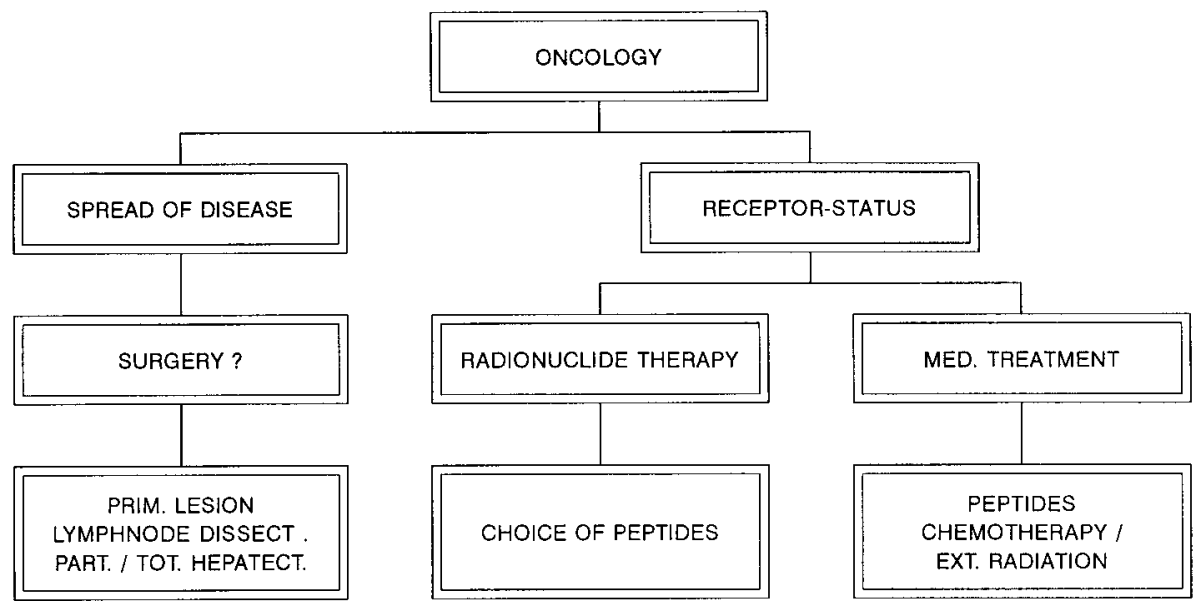

CT, MRI, US

Angiography

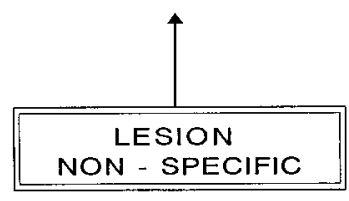

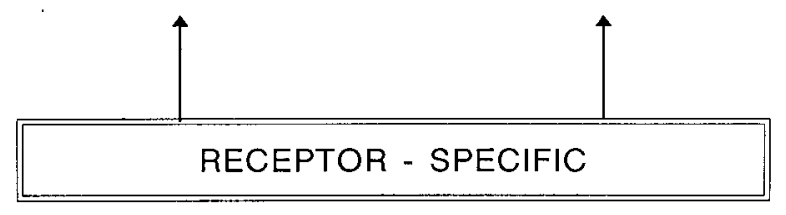

Fig. 2. Scheme of how peptide receptor scintigraphy can influence patient management. The left arm of the scheme depicts the information on tumor spread that peptide scintigraphy may provide. This information may be complementary to conventional imaging techniques and is anatomic in nature. Although this information is based on specific receptor binding, it does not specifically demonstrate one tumor type, as other tumors and inflammatory diseases may also be receptorpositive. Likewise, information obtained with conventional imaging techniques is nonspecific in nature, demonstrating enlargement of structures or differences in signal intensity that may be indicative of tumor but does not prove it. The middle and right arm of the scheme indicate how information on the presence or absence of peptide receptors may influence the choice of nonsurgical therapy. available for radiotherapy. However, radiotherapy with high dose $\left[{ }^{111}\right.$ In-DTPA-D-Phe $\left.{ }^{1}\right]$-octreotide (total dose 20,276 MBq) was recently tried in a patient with a profusely metastasized neuroendocrine tumor [15]. This treatment resulted in reduction of the tumor load by about $20 \%$, probably attributable to Auger electrons or conversion electrons. Despite this promising result, $\beta$-emitting radionuclides are preferable to ${ }^{111}$ In for radiotherapy because of their higher energies and radiation doses and their larger particle ranges. Given the high tumor/background radioactivity ratio observed in carcinoids, it may be expected that once suitable somatostatin analogs coupled to $\beta$-emitting radionuclides are available, effective radiotherapy will be possible.

In summary, octreotide scintigraphy can be applied to localize tumors, to direct the choice of medical therapy, and in the near future to select patients for radiotherapy (Fig. 2). The impact on patient management is fourfold: Octreotide scintigraphy may select resectable tumors that would be unrecognized with conventional imaging techniques; it may prevent surgery in patients whose tumors have metastasized to a greater extent than can be detected with conventional imaging; it may direct the choice of therapy in patients with inoperable tumors; and in the future it may be used to select patients for radionuclide therapy.

\section{Résumé}

Chez 80 à $90 \%$ des patients ayant une tumeur carcinoïde, on peut localiser le site tumoral par la scintigraphie à l'octréotide [ ${ }^{111} \mathrm{In}$ DTPA-D-Phe]. Des localisations inhabituelles sont rencontrées chez un à deux tiers des patients. Dans un groupe de 52 patients, nous avons analysé les résultats de plusieurs types de scintigraphies et de l'imagerie conventionnelle. La scintigraphie à l'octréotide, seule ou combinée à d'autres méthodes d'imagerie, arrive à détecter plus de localisations tumorales que toutes les autres méthodes conventionnelles, même combinées. La combinaison de la scintigraphie à l'octréotide, de la radiographie pulmonaire et de l'échographie de l'abdomen sus-mésocolique ont détecté les lésions chez tous les patients pour lesquels l'imagerie conventionnelle, quel que soit son type, était également révélatrice, avec une sensibilité de $87 \%$. Les coûts par contre étaient plus importants que pour les techniques conventionnelles. Cependant, ces méthodes avaient l'avantage de détecter au moins une lésion insoupçonnée chez $11 \%$ des patients pour lesquels l'imagerie conventionnelle n'était pas parlante. Si les résultats de notre groupe étaient extrapolés à un groupe de 100 patients, la détection des lésions supplémentaires serait obtenue chez 65/100 patients. Surtout, la détection d'autres sites tumoraux chez les patients chez qui une seule localisation est visualisée par des techniques conventionnelles pourrait être décisive avant de déterminer si la chirurgie est indiquée ou pas. La scintigraphie à l'octréotide est utile pour localiser les tumeurs, déterminer la meilleure tactique thérapeutique, et, pour l'avenir, déterminer les patients susceptibles d'un traitement par isotopes. L'impact sur le traitement pour le patient est quadruple: la scintigraphie à l'octréotide peut sélectionner les tumeurs résectables qui n'auraient pas été reconnues avec une technique conventionnelle, elle peut éviter la chirurgie chez les patients ayant plus métastasé que ne le montrent les techniques conventionnelles, diriger la thérapeutique chez les patients non opérables, et enfin, dans l'avenir, sélectionner les patients susceptibles d'être traités par des isotopes.

\section{Resumen}

En $80-90 \%$ de los pacientes con carcinoides la ubicación tumoral puede ser detectada mediante escintigrafia con octreótido. En 
forma inesperada, se reportan ubicaciones adicionales en uno a dos tercios de los pacientes. En un grupo de 52 pacientes hemos analizado los resultados de diversas combinaciones de escintigrafía con octreótido y métodos convencionales de imagenología. La escintigrafía con octreótido, sóla o en combinación con otras modalidades imagenológicas, resultó en la detección de más ubicaciones tumorales que cualquier combinación de técnicas convencionales de imagenología. La combinación de escintigrafía con octreótido, la radiografía de tórax y la ultrasonografía del abdomen superior, permitió la detección de lesiones en la totalidad de los pacientes, con una sensibilidad de $87 \%$ en términos del número de lesiones detectadas. El costo calculado para este régimen de imagenología fue más alto que para la combinación de imagenología convencional. Sin embargo, el beneficio consistió en lograr la detección de por lo menos una lesión en $11 \%$ de los pacientes en quienes con la imagenología no se hallaron anormalidades. Además, al extrapolar los resultados a un grupo de 100 pacientes, la ventaja en términos del número de lesiones extras detectadas fue de 65 por cada 100 pacientes. Este hallazgo de otras ubicaciones tumorales es de importancia esencial en cuanto a la decisión de emprender cirugía en pacientes en quienes sólo se ha identificado una ubicación tumoral única mediante imagenologiá convencional. La escintigrafía con octreótido puede ser aplicada para localizar tumores, para orientar la escogencia de terapia médica y, como se espera que ocurra en el futuro próximo, para seleccionar pacientes para radioterapia. El impacto sobre el manejo de los pacientes es de cuatro clases: la escintigrafía con octreótido puede seleccionar los tumores resecables que pueden permanecer invisibles con las técnicas convencionales de imagenología; puede prevenir la cirugía en pacientes cuyos tumores ya han hecho metástasis de mayor magnitud de la que puede ser detectada con imagenología convencional; puede orientar la escogencia de la terapia en pacientes con tumores inoperables; y, en el futuro, puede ser utilizada para seleccionar pacientes para terapia con radionúclidos.

\section{References}

1. Kvols, L.K., Moertel, C.G., O'Connell, M.J., Schutt, A.J., Rubin, J., Hahn, R.G.: Treatment of the malignant carcinoid syndrome. N. Engl. J. Med. 315:663, 1986
2. Vinik, A.I., Tsai, S.T., Moattari, A.R., Cheung, P., Eckhauser, F.E., Cho, K.: Somatostatin analogue (SMS 201-995) in the management of gastroenteropancreatic tumors and diarrhea syndromes. Am. J. Med. 81(Suppl. 6B):23, 1986

3. Vinik, A.I., McLeod, M.K., Fig, L.M., Shapiro, B., Lloyd, R.V., Cho, K.: Clinical features, diagnosis, and localization of carcinoid tumors and their management. Gastroenterol. Clin. North Am. 18:865, 1989

4. Kvols, L.K.: Therapeutic considerations for the malignant carcinoid syndrome. Acta Oncol. 28:433, 1989

5. Kvols, L.K.: Medical oncology considerations in patients with metastatic neuroendocrine carcinomas. Semin. Oncol. 21(Suppl. 13):56, 1994

6. Reubi, J.C., Maurer, R., von Werder, K., Torhorst, J., Klijn, J.G.M., Lamberts, S.W.J.: Somatostatin receptors in human endocrine tumors. Cancer Res. 47:551, 1987

7. Reubi, J.C., Kvols, L.K., Waser, B., et al.: Detection of somatostatin receptors in surgical and percutaneous needle biopsy samples of carcinoids and islet cell carcinomas. Cancer Res. 50:5969, 1990

8. Krenning, E.P., Kwekkeboom, D.J., Bakker, W.H., et al.: Somatostatin receptor scintigraphy with [ $\left.{ }^{111} \mathrm{In}-\mathrm{DTPA}-\mathrm{D}-\mathrm{Phe}^{1}\right]-$ and $\left[{ }^{123} \mathrm{I}-\mathrm{Tyr}^{3}\right]-$ octreotide: the Rotterdam experience with more than 1000 patients. Eur. J. Nucl. Med. 20:716, 1993

9. Kwekkeboom, D.J., Krenning, E.P., Bakker, W.H., Oei, H.Y., Kooij, P.P.M., Lamberts, S.W.J.: Somatostatin analogue scintigraphy in carcinoid tumours. Eur. J. Nucl. Med. 20:283, 1993

10. Joseph, K., Stapp, J., Reinecke, J., et al.: Receptor scintigraphy with ${ }^{111}$ In-pentetreotide for endocrine gastroenteropancreatic tumors. Horm. Metab. Res. 27(Suppl.):28, 1993

11. Westlin, J.E., Janson, E.T., Arnberg, H., Ahlström, H., Öberg, K., Nilsson, S.: Somatostatin receptor scintigraphy of carcinoid tumours using the $\left[{ }^{111}\right.$ In-DTPA-D-Phe $\left.{ }^{1}\right]$-octreotide. Acta Oncol. 32:783, 1993

12. Ahlman, H., Tisell, L.E., Wängberg, B., Nilsson, O., Forssell-Aronsson, E., Fjälling, M.: Somatostatin receptor imaging in patients with neuroendocrine tumors: preoperative and postoperative scintigraphy and intraoperative use of a scintillation detector. Semin. Oncol. 21(Suppl. 13):21, 1994

13. Kwekkeboom, D.J., Lamberts, S.W.J., Habbema, J.D.F., Krenning, E.P.: Cost-effectiveness of octreotide scintigraphy. (Submitted)

14. Moertel, C.G., Weiland, L.H., Nagorney, D.M., Dockerty, M.B.: Carcinoid tumor of the appendix: treatment and prognosis. N. Engl. J. Med. 317:1699, 1987

15. Krenning, E.P., Kooij, P.P.M., Bakker, W.H., et al.: Radiotherapy with a radiolabeled somatostatin analogue, [ ${ }^{111}$ In-DTPA-D-Phe ${ }^{1}$ octreotide: a case history. Ann. N.Y. Acad. Sci. 733:496, 1994 